\title{
DEVELOPING POLITENESS SKILLS OF UNIVERSITY STUDENTS IN TEACHING BUSINESS WRITING
}

\author{
E.V. Shapkina, shapkinaev@susu.ru \\ South Ural State University, Chelyabinsk, Russian Federation
}

\begin{abstract}
The necessity to improve business interaction and to develop new approaches to study politeness, as an essential category of communication, has determined the need to develop a methodology to teach business writing for future professionals. Thus, the paper aims to study the linguistic politeness means and further develop a system of exercises for university students to write business letters effectively based on the study of politeness. The study uses the descriptive method to determine the choice of linguistic means to express politeness as well as the method of pedagogical construction to produce an effective methodic system to write business letters in English. The results show that business letters use two types of politeness strategies: the intimacy strategy (aiming at establishing and developing business contacts) and the distance strategy (aiming at preventing conflicts). These strategies use a particular set of speech acts that are represented by specific speech cliché or formulas. Finally, the paper suggests the methodic system including five stages: introducing the concept of politeness and its linguistic means; analyzing the means of politeness in sample business letters; developing lexical skills of politeness; writing business letters based on the samples and schemes; practicing reading and writing business letters imitating the real communicative situations.

Keywords: teaching Business English, teaching business writing, teaching technologies, politeness category, politeness theory, politeness strategies.
\end{abstract}

\section{Introduction}

The increased economic activities and business contacts in the world economy raise the issues of effective business interaction between the representatives of different national cultures. Thus, one of the important goals of university studies is to develop the skills providing effective business contacts, and teaching foreign languages plays an important role here.

In a broad sense, it is the society that sets the goal and the demand to develop foreign language skills as a complex basis for further developing both communicative and intercultural competences [7].

One of these requirements is the skill to write business letters in English. The success of this form of communication is largely based on compliance with the principles of polite communication and knowledge of speech etiquette (V. Karasik, M. Koltunova, T. Larina, N. Formanovskaya, G. Leech, M. Haugh etc.) [4, 5, 10-15]. The influence of the genre peculiarities on the content and methods of teaching foreign languages in business communication is reflected in a number of works of modern researchers in the field of methodology and teaching of foreign languages (N. Galskova, N. Gromova, V. Skalkin and etc.) [7, 9, 20]. Nevertheless, some genre features of business letters have not been studied sufficiently yet and need a deeper insight into it. One of the features is a wide range of politeness linguistic means.

The concept of politeness and the principles of behavioral strategies have been thoroughly studied by scholars in the fields of linguistics and speech communication. Of great importance here is the politeness theory developed by the American scientists $\mathrm{P}$. Brown and S. Levinson [3]. They describe politeness as an important category of communication presented in two types of strategies (positive and negative) which are aimed at establishing and developing interpersonal relationships as well as preventing conflict situations.

The basic concepts of the theory help to describe the linguistic means used in the business letters style, which can provide a methodic system to develop business writing skills. Thus, the topicality of the study is determined by the importance of increasing the efficiency of business communication and the need to develop a methodology for business letters writing in English based on the stylistics of the politeness category.

The purpose of our study is to develop a system of exercises aimed at developing the poli- 
teness skills of university students to draw up business letters based on the study of the linguistic means of the politeness category.

The paper sets the following research tasks:

- to define the competence of polite business writing and its structure based on the purpose of teaching business communication in a foreign language for university students;

- to define the peculiarities of business letters genre; theory;

- to present the basic concepts of politeness

- to analyze the compositional, semantic and linguistic means of politeness;

- to make a system of exercises to develop politeness skills for business letters writing.

1. Research methods and materials

To conduct the research,we used two methods:

- the descriptive method for determining the choice of linguistic means to express politeness and the waysof using and combining them in different types of business letters;

- the method of pedagogical construction to producea methodic system aimed at developing a set of skills to use linguistic means of politeness in business letters writing.

The research material covers over 60 example business letters in English, published in a number of business correspondence guides.

\section{Theory}

Contents of teaching a foreign language. Scientifically, the goal and contents of teaching a foreign language is a deliberately planned result of the process to master a language and its culture, achieved through a specific training system, including various methods, techniques and teaching aids [9].

The definition of the goal and contents of teaching a foreign language at a university is directly determined by the competencies presented in the Federal State Educational Standards (FSES) for each area of training. In most FSES, the competence developed at the process of a foreign language studies is characterized by the ability to carry out business communication in oral and written forms in the state language of the Russian Federation and in a foreign language [18].

The competence includes the following skills:

- skills of receptive speech activity (reading and listening) to provide finding, extracting, analyzing and processing information in a foreign language;

- skills of productive speech activity to get in contact with foreign business partners and provide business interaction through a set of oral and written genres of speech communication.

The skills of receptive speech activity in the field of business communication are necessary for university students to extract, organize and analyze all the necessary information in a foreign language.

The skills of productive speech activity in the field provide a direct speech interaction when the participants strive to reach agreement in solving professional problems.

Thus, the structure of business writing competence is based on the following skills:

1) to understand the general content of a business letter and extract the most important information;

2) to get the compositional structure of the letter andreach structural, semantic and functional equivalence;

3) to perceive the variety of contexts through a specific combination of linguistic means based on analyzing the linguistic forms;

4) to inform the recipient about a fact or an event; comment on a fact or an attitude to the subject of communication; to encourage the partner to perform a certain action; to explain or interpret his / her ownideas or reasons towards the business problems; to express agreement or disagreement, refusal or evasion to make a business decision; tomake a claim or complaint; apologize or regret of the claim / complaintreceived; to politely complete a business letter using the means specified by the situations of intercultural communication.

Thus, foreign language business communication is based on a set of productive language skills common for all speech genres. They correlate with the essential parameters of any speech genre in business communication: function, communication goals, structure, types of business letters and language means used in it [9].

Genre peculiarities of business letters. Stylistically, a business letter refers to the official and business style. Its main communicative function is to present information $[1,2,25]$.

Contextually, business letters are divided into sales letters (introducing newproducts, offering price reductions, transport details, making payments etc.), commercial inquiries (asking about terms and discounts, supply of goods, delivery terms, insurance etc.), orders (goods or services), invitations, complaints; confirmations, reminders, recommendations etc. [16]. 


\section{Непрерывное образование в течение жизни...}

Business letters style features objectivity, generality, consistency, explicit semantics, unambiguity. Such features are conveyed with precise wording, set phrases and speech clichés [21].

The compositional structure of business letters is clear and standardized [6]. The structure of a business letter typically includes: printed letter head (name, address, telephone number of a sender, trade mark, etc.), the reference, the date, recipient's address, the attention line, the salutation, the subject line, the main body (presents the basic information, e.g. facts, commercial details, author's attitude, etc.); a complimentary close and a signature [23].

Politeness theory. Politeness plays a key role for successful communication in different spheres of human activities [22]. Polite communication is based on tact, nobility, approval, restraint, benevolence, mutual understanding [12]. In a broad sense, politeness is associated with the desire to demonstrate friendly attitude towards the partner and receive a similar response [8].

As we noted above, politeness studies can be based on the theory proposed by the American scholars P. Brown and S. Levinson. It explains politeness as a concept and provides the analytical tools for the deeper insight in it.

Their theory considers two basic types of politeness: positive and negative ones. They correlated with social strategies of behavior. Positive strategies of polite behavior show partners' interest in cooperation, initiative displaying and encouraging, care and attention to partner's problems and interests, communicative optimism. Negative strategies of polite behavior demonstrate the implicit sender's and recipient' intentions, pursuing only their own interests, low selfesteem, desire for subordination, distance and apology, communicative pessimism [3].

Based on the theory, the Russian linguist $\mathrm{T}$. Larina has made some more detailed insights into the nature of politeness. In particular, she uses the terms "intimacy strategies" and "distance strategies" for "positive" and "negative" speech strategies. Intimacy strategies involve positive emotions, communicative optimism, wish to give a help and an interest to develop interpersonal relations. Distance strategies include interpersonal subordination, personal privacy, communicative pessimism. In our study we will use the terms by V. Larina to describe the types of politeness due to their greater semantic transparency.

Her approach also postulates that the linguistic means of both strategies have national specifics in different languages, which is very important for our study. Thus, in similar communicative situations, the British use distance strategies, which is not typical for the Russians. Conversely, in a number of situations, the Russians demonstrate emotional reservation (distance strategies), but the British demonstrate affability (intimacy strategies). Proper using these strategies provides success in intercultural business communication.

According to T. Larina, politeness, as a linguistic category, is expressed through a certain set of speech acts. In particular, intimacy strategies involve speech acts of greeting, saying goodbye, compliment, gratitude, invitation, apology. Distance strategies involve speech acts of orders, commands, advice, requests, instructions, etc. [14, pp. 142-190].

In business communication, polite interaction implies respectful and benevolent attitude towards a business partner, a certain interpersonal distance, tolerance to other people's opinions, effective reasoning, etc. The interaction is based on the principles of business etiquette, which is a set of certain conventional rules of personal behavior determined by the sphere of business communication [17, p. 296].

Linguistically, politeness is largely based on the rules of speech etiquette defined as "a set of developed rules of speech behavior, a system of speech communication formulas" [24, p. 139].

These speech formulas use a certain set of linguistic means related to different levels of language: lexical (words and expressions), grammatical (grammatical forms of words) and syntactic (word order, types of sentences, etc.).

In business letters style, speech etiquette includes salutation and complimentary close formulas, the way the sender expresses gratitude, recommendations, requests, refusals, claims, etc. [19]. These speech tools have their specifics in different languages [10].

\section{Results}

\subsection{Politeness Analysis}

Our study showed that all the types of business letters can be divided into two groups: letters that provide intimacy strategies (inquiries, orders, offers, sales letters, business proposals, counter proposals, invitation and congratulation letters, etc.) and letters that use distance strategies (reminders, complaints, answers to complaints, refusals, etc.).

The more detailed analysis showed that intimacy strategies in business letters include saluta- 
tions and complimentary closes, invitations for business meetings and appointments, business proposals, gratitude, expressing hopes for further cooperation, etc.; distance strategies include requests, recommendations, refusals, apologies, warnings, reminders, claims, etc.

Our study found that one letter typically includes several polite speech acts. First of all, this is a greeting and saying goodbye and at least two other speech acts. They are typically combined into pairs: a business proposal + a hope for further cooperation; a gratitude + a hope for further cooperation; a reminder + a hope for further cooperation; a request + a gratitude; a gratitude + a request, etc. The use of these combinations depends on the type of a business letter.

Structurally, politeness tools are used in the introductory and concluding parts of a business letter. The introductory part uses a salutation plus the first speech act of a typical pair and the concluding part uses the second act plus a complimentary close (saying good-buy). Thus, politeness tools "frame" the content of a business letter.

The introductory part of a business letter typically includes such speech acts as: a salutation, a business proposal, a gratitude, a reminder, a request, arecommendation, a claim. The final part typically contains a hope for an early response or further cooperation, a request, a gratitude.

Schematically, using politeness means within the structure of a business letter can be presented in the scheme (Fig. 1).

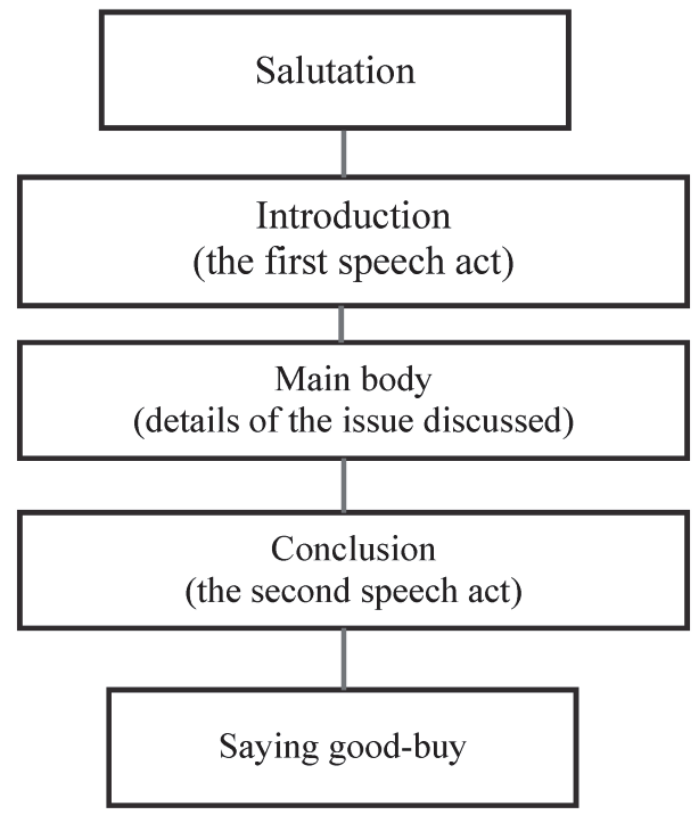

Fig. 1. Politeness means within the structure of a business letter
Our study found that politeness has a certain structural model that depends on the letter type. Here are some sample models.

Inquiry letters. They contain asking for some information about the supply of goods, terms and discounts, insurance, etc.

Model 1. Salutation + request + thanks + complimentary close.

Model 2. Salutation + business proposal + hope for further cooperation + complimentary close.

Business offer letters. They present a business proposal to supply a special product or a range of goods etc.

Model 1. Salutation + business proposal + hope for further cooperation + complimentary close.

Model 2. Salutation + thanks + hope for further cooperation + complimentary close.

Order letters. They contain a request to supply a product or provide a service.

Model 1. Salutation + request + thanks + complimentary close.

Model 2. Salutation + request + hope for further cooperation + complimentary close.

Gratitude letters. They express thanks for fulfilling requests, hospitality, information, recommendation, assistance, etc.

Model 1. Greeting + thanks + hope for further cooperation + complimentary close.

Model 2. Greeting + gratitude + request + complimentary close.

Claiming letters. They contain informing about a problem and the demand for its elimination or compensation.

Model 1 . Greeting + claim + hope for an early response + complimentary close.

Model 2. Greeting + claim + request + complimentary close.

The analysis of politeness tools found their specifics at all the three language levels - lexical, grammatical and syntactic. The lexical level is represented, first of all, by words and expressions that directly express politeness, e.g. performative verbs (to thank, to advice, to remind, to request, etc.); verbal phrases (to be disappointed, be to be pleased, to be interested in, to look forward to, to draw someone's attention, etc.); and the word "please". The grammatical level includes the inverted word order in the form of a question (May we advise you ...); and the subjunctive mood (I would like to ...). The syntactic level is represented by declarative or interrogative simple sentences. 


\section{Непрерывное образование в течение жизни...}

The grammatical and lexical analysis has the following results.

Salutations. This speech act is used in all the business letters. It is represented by both purely official and less official formulas ("Dear Sir (s)", "Dear Madam", "Dear Mr. Hampshire", "Dear Josef", etc.).

Complimentary closes. This speech action is used in all the business letters as well. The choice of the speech formula depends on the relationship between the business partners. In formal relations such phrases as "Very truly yours", "Sincerely yours" are used and in the less formal relations "Cordially yours", "Yours", "Sincerely", "With kind regards", etc.

Expressing hope for further cooperation. Typically, this speech act is expressed with the performative verb "hope", as well as the noun "hope", e. g. "In the hope that we can come to terms ...", etc.

Gratitude (Thanks). In business letters, gratitude and appreciation are expressed with verbal and nominative phrases, e. g. "I would very much appreciate it if you ...", "We are very pleased to confirm ...", etc.

Claims. To mitigate the communicative effect of claims and author's dissatisfaction various linguistic means, both grammatical and lexical, are used: the subjunctive mood, e. g. "I wish to complain", "We would appreciate it if", "Unfortunately", "I am disappointed because...", etc.

Apologies. The most common means are the verb "to apologize" and the noun "apology" combined with a range of lexical means that providea positive communicative effect, e.g." $W e$ apologize for ...", "Please accept our sincere apologies for this delay", "We offer an apology for ...", etc.

\subsection{Developing a system of exercises}

To do it, we use the principles of the methodic theory by N. Gromova [9]. The theory is based on the five stages to teach a foreign language in business communication:

Stage 1. Developing a general overview of the business texts contents, their compositional structure and typical language means.

Stage 2. Analyzing some sample texts for their content, compositional structure and linguistic means.

Stage 3. Developing language skills to use typical phrases necessary for business texts reading or producing.

Stage 4. Developing the skills of prepared oral and written speech for business texts reading or producing.

Stage 5. Developing the skills of unprepared oral and written speech for business texts reading or producing [9, pp. 232-237].

Based on the stages, we propose the following system of teaching business letters writing.

Stage 1. It includes a range of business texts in a foreign language introducing the concept of politeness as a means to provide the effective intercultural business contacts; politeness strategies aiming at establishing and developing business contacts (positive strategies) and avoiding conflicts (negative strategies); using politeness means in different structural parts of a business letter and their specifics (at the lexical, grammatical and syntactic levels). At the stage, students study the example letters of all the types in a foreign language.

The suggested types of exercises:

1. Read the text and answer the questions (on the text).

2. Read the text and choose the true statements.

3. Think about the situations of polite and impolite people's behavior. Tell your groupmates.

4. Read the letter. What structural parts does it have?

5. Put the parts of the letter in the correct order.

6. Divide the politeness means into two groups: positive and negative ones.

7. Read the letters. Which letters use the politeness means?

8. Read the letters. What kinds are they? What politeness strategies do they use? Which linguistic means do they express?

Stage 2. It aims at developing a set of skills to produce texts through analyzing sample business letters. At the stage students study sample business letters paying attention to how the politeness means are used depending on the letter type and its place in the compositional structure.

The suggested types of exercises:

1. Define the type of the business letter and analyze its compositional structure.

2. Read the letters. Make the politeness patters.

Example: "Salutation + claim + request + complimentary close".

3. Define the type of the business letter based on the pattern given. 
4. Read the letters. Check the linguistic means of politeness used in them.

5. Read the letter below. Check the phrases of request, expressing hope for further cooperation, a recommendation, a claim, thanks, etc.

6. Use the missing phrases from the box in the gaps.

Stage 3. The stage develops the lexical skills of politeness. Students practice using standard politeness phrases and speech formulas in business letters of different types.

The suggested types of exercises: flicts.

1. Check the phrases used to prevent con-

2. Match the words from the columns to make politeness phrases.

3. Match the politeness phrases and the speech acts. below.

4. Make polite requests using the phrases

5. Restore the correct word order in the sentences below. below.

6. Give the synonyms for the phrases

7. Choose the politeness phrases for the situations below.

8. Read the claim below. Check the politeness phrases used in it. Change them to produce less rigorous and more rigorous effect.

9. Read the letter below. Add politeness phrases where necessary.

Stage 4. The stage develops skills to read and write letters of different types. Students practice reading and writing business letters based on the samples and schemes.

The suggested types of exercises:

1. Write a gratitude letter. Choose the introduction, the main body and complimentary close.

2. Write an order / a reminder / claiming / a request letter choosing the necessary phrases from the list.

3. Write the introduction, the main body and the complimentary close for an offer letter.

4. Read the advertising letter. Write a response to it based on the plan and the details below.

Stage 5. It also aims at practicing reading and writing business letters imitating the real communicative situations. It needs a kind of creative thinking.

The suggested types of exercises:

1. You work for the Image Company. Write a gratitude letter to the Real Company. Give your thanks for the good quality and on-time delivery of the office equipment.
2. Read the invitation letter to take part in the business forum from your partner from the USA. Write a response with thanks and the request to give some more details of it.

3 . Read the complaint letter. Write a response to it as if you accept / don't accept it.

4. Read the quotation below and write an order letter.

5. Read the contract below and write a business offer letter.

6. You bought a fridge but it doesn't work. Write a letter to the producer asking to refund it.

\section{Discussion}

Teaching business letters writing for university students aims at developing skills of receptive and productive speech activities. The former includes understanding the general content of a business letter and extracting the most important information, which needs good knowledge of lexical, grammatical means and its compositional structure. The latter includes the skills for the direct business interaction when the partners can inform the partners, make business contacts, agree or disagree with the partner's opinion, make a polite refusal, request, claim or apology.

The study showed that the skills are based not only on the basic genre peculiarities, as communicative aims, business letters types, compositional structure and linguistic means, but politeness formulas as well.

Business letters style demonstrates two types of politeness strategies: the intimacy strategies (aiming at establishing and developing business contacts) and the distance ones (aiming at preventing conflicts). These strategies use a particular set of speech acts which were found in all the letters analyzed, such as: greeting and salutation, expressing hope for further cooperation and hope for an early response, gratitude, requests, business offers, recommendations, reminders, claims, complimentary closes and saying goodbye. Each letter has at least two politeness speech acts combined into typical pairs. Linguistically, politeness strategies are represented by speech cliché or formulas with their specifics on all the language levels: lexical, grammatical and syntactical ones.

Methodically, the suggested system of teaching business letters writing includes five stages:

1. Introducing the concept of politeness and its linguistic means.

2. Analyzing means of politeness in sample business letters.

3. Developing lexical and grammatical skills of politeness. 
Непрерывное образование в течение жизни...

Table 1

Correlation between system of exercises and basic concepts

\begin{tabular}{|l|c|l|}
\hline \multicolumn{1}{|c|}{ Skills type } & $\begin{array}{c}\text { Stage } \\
\text { of exercises }\end{array}$ & \multicolumn{1}{|c|}{ Politeness concepts and means } \\
\hline $\begin{array}{l}\text { Skill 1. Understanding the general content } \\
\text { of a business letter }\end{array}$ & Stage 1 & $\begin{array}{l}\text { Concepts of positive (intimacy) and negative } \\
\text { (distance) politeness strategies and corresponding } \\
\text { letter types }\end{array}$ \\
\hline $\begin{array}{l}\text { Skill 2. Getting the compositional } \\
\text { structure of a letter }\end{array}$ & Stage 2 & $\begin{array}{l}\text { Typical models of politeness speech acts; } \\
\text { their position within the structure of a letter } \\
\text { depending on the letter type }\end{array}$ \\
\hline $\begin{array}{l}\text { Skill 3. Recognizing and using specific } \\
\text { combinations of linguistic means }\end{array}$ & Stage 3 & $\begin{array}{l}\text { Typical lexical and grammatical means used } \\
\text { in particular speech acts }\end{array}$ \\
\hline $\begin{array}{l}\text { Skill 4. Writing business letters based } \\
\text { on the politeness models }\end{array}$ & Stage 4 & $\begin{array}{l}\text { Typical sets of linguistic means for particular } \\
\text { politeness models depending on the letter type }\end{array}$ \\
\hline $\begin{array}{l}\text { Complex of all the skills (competence) } \\
\text { needed for successful business letters writing }\end{array}$ & $\begin{array}{l}\text { All the range of the presented concepts and } \\
\text { politeness means }\end{array}$ \\
\hline
\end{tabular}

4. Reading and writing business letters based on samples and schemes.

5. Practicing reading and writing business letters imitating the real communicative situations.

The suggested system of exercises tightly correlates with all the basic concepts considered (competence of polite business writing, genre peculiarities, politeness theory) as well as linguistic and structural analysis conducted, as it is demonstrated in the table 1 .

\section{Conclusion}

Our study shows that the results of analyzing linguistic and compositional peculiarities of business letters genre, based on new politeness theories, help to detail the structure of competence in the sphere of written business communication, which, in its turn, determine the contents and stages of a teaching process. The stages of developing the competence demonstrate successive process based on forming skills of receptive and productive speech.

The system of exercises can be used in developing textbooks on Business English or Business Writing, or as supporting materials at the English classes for university students.

\section{References}

1. Arnold I.V. Stilistika. Sovremennyy angliyskiy yazyk [Stylistics. Modern English]. Moscow, Flinta: Nauka Publ., 2002. 384 p.

2. Arutyunova N.D. Zhanry obshcheniya [Communication Genres]. Human Factor in Language. Communication, Modality, Deixis, M., 1992, pp. 52-56.

3. Brown P., Levinson S. Politeness: Some Universals in Language Use. The Discourse Reader. London and New York, 2004, pp. 328-335.
4. Formanovskaya N.I. Kul'tura obshcheniya $i$ rechevoy etiket [Communication Culture and Speech Etiquette]. Moscow, IKAR Publ., 2004. $236 \mathrm{p}$.

5. Formanovskaya N.I. Russkiy rechevoy etiket: lingvisticheskiy $i$ metodicheskiy aspekty [Russian Speech Etiquette: Linguistic and Methodological Aspects]. Moscow, 1987. 240 c.

6. Galperin I.R. Tekst kak ob"yekt lingvisticheskogo issledovaniya [Text as an Object of Linguistic Research] Moscow, Nauka Publ., 1981. $137 \mathrm{p}$.

7. Galskova N.D. Sovremennaya metodika obucheniya inostrannym yazykam [Modern Methods of Teaching Foreign Languages]. Moscow, ARKTI Publ., 2003. 192 p.

8. Graudina L.K. Kul'tura russkoy rechi [The Culture of Russian Speech]. Moscow, Izdatel'stvo NORMA Publ., 2002. 560 p.

9. Gromova N.M. Delovoe obshchenie na inostrannom yazyke [Business Communication in a Foreign Language]. Moscow, Magister: INFRA-M Publ., 2010, pp. 183-237.

10. Haugh M. The Constitution of Politeness Implicature in Conversation. Journal of Pragmatics, 2007, vol. 39, pp. 243-257. DOI: 10.1016/j.pragma.2006.07.004

11. Karasik V.I. Yazyk sotsial'nogo statusa [The Language of Social Status]. Moscow, Institut yazykoznaniya AN SSSR Publ., 1991. 495 p.

12. Koltunova M.V. Yazyk i delovoe obshchenie: normy, ritorika, etiket [Language and Business Communication: Norms, Rhetorics, Etiquette]. Moscow, Ekonomicheskaya Literatura Publ., 2002. 288 p.

13. Larina T.V. [English Style of Phatic Communication]. Genres of Speech, 2005, iss. 4, pp. 251-262. (in Russ.) 
14. Larina T.V. [Politeness in Consciousness and Communication: Intercultural Aspect]. Mezhdunarodnyy sbornik nauchnykh trudov "Aktual'nye problemy kommunikatsii i kul'tury 2" [International Collection of Scientific Papers "Actual Problems of Communication and Culture 2"]. Pyatigorsk, 2005. 304 p. (in Russ.)

15. Leech G. Principles of Pragmatics. London, New York, Longman Publ., 1983. $250 \mathrm{p}$.

16. Maksimov V.I. Stilistika i literaturnoe redaktirovaniye [Stylistics and Literary Editing]. Moscow, Gardariki Publ., 2004. 561 p.

17. Naterop B.J. Business Letters for All. Oxford University Press Publ., 2000. 103 p.

18. Portal Federal'nykh gosudarstvennykh obrazovatel'nykh standartov vysshego obrazovaniya [Portal of Federal State Educational Standards of Higher Education]. Available at: http:// fgosvo.ru/ (accessed 25.09.2020).

19. Shapkina E.V. [Features of the Translation of the Linguistic Category of Politeness in
Business Correspondence]. Languages. Cultures. Transfer, 2015, no. 1, pp. 302-309. (in Russ.)

20. Skalkin V.L. Osnovy obucheniya ustnoy inoyazychnoy rechi [Fundamentals of Teaching Oral Foreign Speech]. Moscow, Russkiy yazyk Publ, 1981. 182 p.

21. Solganik G.Ya. Stilistika teksta [Stylistics of the Text]. Moscow, Flinta: Nauka Publ., 1997. $252 \mathrm{p}$.

22. Soloviev E.Ya. Sovremennyy etiket. Delovoy $i$ mezhdunarodnyy protocol [Modern Etiquette. Business and International Protocol]. Moscow, Os'-89 Publ., 2003. 320 p.

23. Trofimova O.V., Kupchik E.V. Osnovy delovogo pis'ma [Basics of Business Letters]. Moscow, Flinta: Nauka, 2010. 303 p.

24. Vinogradov V.V. Problemy russkoy stilistiki [Problems of Russian Stylistics]. Moscow, Higher School Publ., 1981. 320 p.

25. Znamenskaya T.A. Stilistika angliyskogo yazyka [Stylistics of the English Language]. Moscow, Editorial URSS Publ., 2002. 208 p.

Received 23 February 2021

\title{
ФОРМИРОВАНИЕ НАВЫКОВ ВЕЖЛИВОГО ОБЩЕНИЯ В ПРОЦЕССЕ ОБУЧЕНИЯ ДЕЛОВОМУ ПИСЬМУ В ВУЗЕ
}

\author{
E.В. Шапкина \\ Южно-Уральский государственный университет, г. Челябинск, Россия
}

\begin{abstract}
Статья посвящена вопросам формирования навыков эффективного межкультурного взаимодействия студентов вузов в области деловой переписки на английском языке. Актуальность настоящей работы определяется значимостью повышения эффективности делового общения в условиях расширения межкультурных деловых связей. Целью исследования является изучение лингвистических средств вежливости с последующей разработкой системы упражнений, направленных на формирование навыков вежливого общения в деловой переписке на английском языке студентов вузов. Методы исследования: описательный метод, предполагающий наблюдение и описание языковых средств вежливости; метод конструирования педагогического процесса, предполагающий разработку системы упражнений. Научная новизна работы заключается в изучении реализации категории вежливости в деловой переписке с использованием новейших подходов к изучению данной категории, а также применении полученных результатов в системе обучения иноязычному деловому общению. В результате исследования выявлена и описана специфика лингвистических средств вежливости в зависимости от тематической направленности и композиционной структуры деловых писем. На основе данных результатов разработана методика обучения деловой переписке студентов вузов, предполагающая комплекс упражнений, который имеет пять стадий формирования навыков: формирование общего представления об общем содержании деловых писем, их композиционной структуре и речевых особенностях; анализ готовых образцов текстов на предмет содержательных, композиционных и языковых особенностей делового общения; формирование языковых навыков использования
\end{abstract}


стандартных фраз, необходимых для восприятия и создания деловых писем; умений подготовленной и неподготовленной устной или письменной речи при восприятии и порождении деловых писем.

Ключевые слова: обучение деловому английскому языку, обучение деловому письму, технологии обучения, категория вежливости, стратегии вежливого поведения, деловая коммуникация.

\section{Литература}

1. Арнольд, И.В. Стилистика. Современный английский язык / И.В. Арнольд. - М.: Флинта: Наука, 2002. - 384 c.

2. Арутюнова, Н.Д. Жанры общения / Н.Д. Артюнова // Человеческий фактор в языке. Коммуникация, модальность, дейксис. - М., 1992. - C. 52-56.

3. Brown P., Levinson S.C., Politeness: some universals in language use / P. Brown, S.C. Levinson. The discourse Reader. - London and New York, 2004. - P. 328-335.

4. Формановская, Н.И. Культура общения и речевой этикет / Н.И. Формановская. - М.: ИКАР, 2004. - 236 с

5. Формановская, Н.И. Русский речевой этикет: лингвистический и методический аспекты / Н.И. Формановская. - М., 1987. - 240 с.

6. Гальперин, И.Р. Текст как объект лингвистического исследования / И.Р. Гальперин. - М.: Наука, 1981. - 137 c.

7. Гальскова, Н.Д. Современная методика обучения иностранным языкам / Н.Д. Гальскова. М.: АРКТИ, 2003. -192 c.

8. Граудина, Л.К. Культура русской речи / под ред. проф. Л.К. Граудиной. - М.: НОРМА, 2002. $-560 \mathrm{c}$.

9. Громова, Н.М. Деловое общение на иностранном языке: методика обучения / Н.М. Громова. - М.: Магистр: ИНФРА-М, 2010. - С. 183-237.

10. Haugh, M. The constitution of politeness implicature in conversation / M. Haugh // Journal of Pragmatics. - 2007. - Vol. 39. - P. 243-257.

11. Карасик, В.И. Язык социального статуса / В.И. Карасик. - М.: Ин-т языкознания AH CCCP, 1991. -495 c.

12. Колтунова, М.В. Язык и деловое общение: Нормы, риторика, этикет / М.В. Колтунова.М.: Эконом. лит., 2002. -288 с.

13. Ларина, Т.В. Английский стиль фатической коммуникации / Т.В. Ларина // Жанры речи. 2005. - Bbln. 4. - C. 251-262.

14. Ларина, Т.В. Вежливость в сознании и коммуникации: межкультурный аспект / Т.В. Ларина // Актуальные проблемь коммуникации и культуры: междунар. сб. науч. тр. Пятигорск, 2005. - $304 \mathrm{c}$.

15. Leech, G. Principles of pragmatics / G. Leech. - London, New York: Longman, 1983. - 250 p.

16. Максимов, В.И. Стилистика и литературное редактирование / В.И. Максимов. М.: Гардарики, 2004. - 561 c.

17. Naterop, B.J. Business letters for all. - Oxford University Press, 2000. - 103 p.

18. Портал Федеральных государственных образовательных стандартов выстего образования. - http://fgosvo.ru/ (дата обращения: 25.09.2020).

19. Шапкина, Е.В. Особенности перевода лингвистической категории вежливости в деловой корреспонденции / Е.В. Шапкина // Языки. Культуры. Перевод. - 2015. - № 1. - С. 302-309.

20. Скалкин, В.Л. Основы обучения устной иноязычной речи / В.Л. Скалкин. - М.: Рус. яз., 1981. $-182 c$.

21. Солганик, Г.Я. Стилистика текста. - М.: Флинта: Наука, 1997. - 252 с.

22. Соловьев, Э.Я. Современный этикет. Деловой и международный протокол / Э.Я. Соловьев. - М.: Ocb-89, 2003. $-320 c$.

23. Трофимова, О.В. Основы делового письма / О.В. Трофимова, Е.В. Купчик. - М.: Флинта: Наука, 2010. - 303 c. 
24. Виноградов, В.В. Проблемь русской стилистики / В.В. Виноградов. - М.: Выси. икк, 1981. $-320 \mathrm{c}$.

25. Знаменская, Т.А. Стилистика английского языка / Т.А. Знаменская. - М.: Едиториал УPCC, 2002. -208 c.

Шапкина Елена Валерьевна, кандидат филологических наук, доцент, доцент кафедры «Иностранные языки», Южно-Уральский государственный университет, г. Челябинск, shapklinaev@susu.ru.

Поступила в редакцию 23 февраля 2021 z.

\section{ОБРАЗЕЦ ЦИТИРОВАНИЯ}

Shapkina, E.V. Developing Politeness Skills of University Students in Teaching Business Writing / E.V. Shapkina // Вестник ЮУрГУ. Серия «Образование. Педагогические науки». - 2021. - Т. 13, № 2. - С. 24-33. DOI: $10.14529 /$ ped 210202

\section{FOR CITATION}

Shapkina E.V. Developing Politeness Skills of University Students in Teaching Business Writing. Bulletin of the South Ural State University. Ser. Education. Educational Sciences. 2021, vol. 13, no. 2, pp. 24-33. DOI: 10.14529/ped210202 